\title{
SCREENING OF PHYTOCHEMICALS AND IN VITRO ANTIDIABETIC ACTIVITY OF BAUHINIA RACEMOSA LAM. LEAVES
}

\author{
BHIMRAJ GAWADE ${ }^{1 *}$, MAZAHAR FAROOQUI ${ }^{2}$ \\ ${ }^{1}$ Department of Chemistry, A. D. College, Kada, Maharashtra, India. ${ }^{2}$ Department of Chemistry, Dr. Rafiq Zakaria College for Women, \\ Aurangabad, Maharashtra, India. Email: mazahar_64@rediffmail.com
}

Received: 01 February 2018, Revised and Accepted: 24 February 2018

\section{ABSTRACT}

Objective: In this study, the leaves of medicinal plant Bauhinia racemosa Lam. with different pharmacological activities were subjected to phytochemical screening and assessment of their in vitro inhibitory potential with porcine pancreatic $\alpha$-amylase enzyme to treat and management of diabetes.

Methods: Plant leaves were extracted sequentially with ethanol solvent. A modified 3,5-dinitrosalicylic acid method was adopted to screen $\alpha$-amylase inhibition assay. The ethanol extract was analyzed qualitatively and gas chromatography-mass spectrometry analysis technique for the active phytoconstituents according to the standard protocols.

Results: A phytochemical screening of leaves extract reveals the presence of carbohydrate, alkaloids, saponin, glycosides, steroids, tannins, flavonoids,

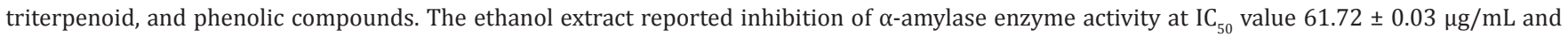
acarbose as a standard drug at $\mathrm{IC}_{50}$ value $28.07 \pm 0.02 \mu \mathrm{g} / \mathrm{mL}$.

Conclusion: The results of the study indicate that B. racemosa Lam. leaves contain some of bioactive phytochemicals might to be exhibiting in vitro antidiabetic activity, which was leading to decreases the rate of starch digestion.

Keywords: Bauhinia racemosa Lam., Pharmacological, $\alpha$-amylase, Phytochemical, Antidiabetic.

(C) 2018 The Authors. Published by Innovare Academic Sciences Pvt Ltd. This is an open access article under the CC BY license (http://creativecommons. org/licenses/by/4. 0/) DOI: http://dx.doi.org/10.22159/ajpcr.2018.v11i6.24038

\section{INTRODUCTION}

A chronic metabolic disorder of insulin deficiency or ineffectiveness is resulted into diabetes mellitus. It causes a global health burden on public and predictions of it estimate that India, China, and the United States will have the highest number of diabetic people up to the year 2030 [1]. Antidiabetic agents synthetically prepared could be produced serious side effects [2]. The search for plant-based medicine for control of diabetes mellitus continues, and the World Health Organization has also recommended about herbal treatment on diabetes mellitus [3].

Medicinal plants were reporting traditionally antidiabetic activity [4]. These contain active chemical constituents are inhibited $\alpha$-amylase enzyme, and it prevents dietary starches from being digested and absorbed by the body. Antinutrient acting $\alpha$-amylase inhibitors are responsible to control rate of starch digestion and absorption. Furthermore, potentially become useful in control of obesity and diabetes like disorders. Hence, they are useful for treating diabetes mellitus Type-II.

The Bauhinia racemosa Lam. plant is exhibits various pharmacological activities reported as analgesic, antipyretic, antiinflammatory [5], antispasmodic [6], anthelmintic, antimicrobial activity [7], and antioxidant [8,9] as well. Due to the presence of several active phytoconstituents [10], this synthesizes primary and secondary metabolites having benefits in traditional system of medicine [11].

Various scientific studies have confirmed the beneficial effect of plants with antidiabetic activity in the traditional management of diabetes mellitus [12] on streptozotocin and alloxan-induced diabetic animal models [13].

The study has been reported that different plant isolates possess vast potentiality of leaves ethanol extract in vitro antidiabetic activity.
Therefore, the leaves ethanol extract of B. racemosa Lam. plant was subjected to study phytochemical screening and assessment of their in vitro antidiabetic potential.

\section{METHODS}

Collection of plant material

The $B$. racemosa Lam. plant leaves were collected from local area identified and authenticate with the help of botanist from our institute. The plant leaves rinsed with distilled water and dried in shade at room temperature.

\section{Preparation of extract}

The air-dried leaves of $B$. racemosa Lam. were finely crushed and powdered. $10 \mathrm{~g}$ of powdered plant material was dissolved in $100 \mathrm{~mL}$ of ethanol and kept on a magnetic stirrer for $2 \mathrm{~h}$. Thereafter, it was extracted using a Soxhlet apparatus sequentially with ethanol. The extract was collected and the solvent was evaporated out to dryness. The obtained material was stored at $4^{\circ} \mathrm{C}$ in airtight bottles for further screening studies.

\section{In vitro $\alpha$-amylase inhibitory assay screening}

A modified 3,5-dinitrosalicylic acid (DNSA) method was adopted to screen $\alpha$-amylase inhibition activity, by quantifying the reducing sugar (maltose) liberated under the assay conditions. The enzyme inhibitory activity was expressed as a decrease in units of maltose liberated $[14,15]$.

\section{Phytochemical screening}

The ethanol extract of $B$. racemosa Lam. was screened qualitatively for the active phytoconstituents such as alkaloids, carbohydrate, protein, amino acids, glycoside, tannins, saponin, flavonoids, steroids, terpenoids, and phenolic compounds according to the standard protocol $[16,17]$. 
Gas chromatography-mass spectrometry (GC-MS) analysis

GC-MS analysis was carried out on Shimadzu GC-MS model number QP 2010S. The column Rxi-5Sil MS, 30 meter length, $0.25 \mathrm{~mm}$ ID, and $0.25 \mu \mathrm{m}$ thickness, was used. The organic compounds were identified by comparison of mass spectra with the inbuilt libraries NIST-11 and WILEY-8.

\section{Statistical analysis}

The experimental tests were performed triplicate in three sets and the results expressed in mean \pm SD. Values of $p<0.05$ were considered as statistically significant.

\section{RESULTS}

The ethanol extract of $B$. racemosa Lam. leaves results showed that it exhibited dose-dependent porcine pancreatic $\alpha$-amylase inhibitory activities by in vitro assay using potato starch as substrate.

\section{In vitro alpha-amylase inhibition assay}

The antidiabetic activity was investigated through the inhibition of $\alpha$-amylase, an enzyme that made the digestion of starch and so reduced the glucose absorption. Acarbose is a standard drug at a concentration of $20-100 \mu \mathrm{g} / \mathrm{mL}$ showed $\alpha$-amylase inhibitory activity from $47.17 \%$ to $68.81 \%$ with an $\mathrm{IC}_{50}$ value $28.07 \pm 0.02 \mu \mathrm{g} / \mathrm{mL}$, whereas ethanol extract $(20-100 \mu \mathrm{g} / \mathrm{mL})$ of $B$. racemosa Lam. exhibited potent $\alpha$-amylase inhibitory activity in a dose-dependent manner from $41.91 \%$ to $54.78 \%$ with an $\mathrm{IC}_{50}$ value of $61.72 \pm 0.03 \mu \mathrm{g} / \mathrm{mL}$ (Table 1 and Fig. 1).

\section{Phytochemical screening}

The qualitative phytochemical screening of the ethanol extract confirms the presence of alkaloids, carbohydrate, protein, amino acids, glycoside, tannins, saponin, flavonoids, steroids, and phenolic compounds as shown in Table 2.

\section{GC-MS analysis}

A GC-MS of the ethanol extract was carried out up to maximum $44.0 \mathrm{~min}$, which shows six different peaks. The first peak appears at 16.536 min retention time. The maximum peak area was found at retention time $21.276 \mathrm{~min}$ as in chromatogram (Fig. 2). The library search shows six compounds (Table 3); out of these, neophytadiene is maximum amount. It will be interesting to investigate further the bioactivity of this compounds when isolated in pure form.

Table 1: $\% \alpha$-amylase inhibition assay of standard and B. racemosa Lam. extract

\begin{tabular}{lll}
\hline Concentration in $\mu \mathbf{g} / \mathbf{m L}$ & $\begin{array}{l}\text { \% inhibition } \\
\text { of standard }\end{array}$ & $\begin{array}{l}\text { \% inhibition } \\
\text { of extract }\end{array}$ \\
\hline 20 & $47.17 \pm 0.04$ & $41.91 \pm 0.02$ \\
40 & $54.38 \pm 0.02$ & $43.86 \pm 0.01$ \\
60 & $59.45 \pm 0.02$ & $49.90 \pm 0.02$ \\
80 & $64.32 \pm 0.00$ & $52.05 \pm 0.03$ \\
100 & $68.81 \pm 0.01$ & $54.78 \pm 0.05$ \\
IC50 value $(\mu \mathrm{g} / \mathrm{mL})$ & $28.07 \pm 0.02$ & $61.72 \pm 0.03$ \\
\hline B. racemosa: Bauhinia racemosa & &
\end{tabular}

Table 2: Phytochemical screening of Bauhinia racemosa Lam. extract

\begin{tabular}{lc}
\hline Phytochemicals & Result \\
\hline Alkaloid & + \\
Carbohydrate & + \\
Protein and amino acids & + \\
Glycoside & + \\
Tannin & + \\
Saponin & + \\
Flavonoids & + \\
Steroids & + \\
Triterpenoids & - \\
Phenolic compounds & + \\
\hline
\end{tabular}

+: For present, -: For absent

\section{DISCUSSION}

In vitro antidiabetic activity was screened using $\alpha$-amylase inhibitory assay modified DNSA method. As compared to standard drug ethanol extract of B. racemosa Lam. leaves showed significant antidiabetic activity. The ethanol extract reported inhibition of $\alpha$-amylase at $\mathrm{IC}_{50}$ value $61.72 \pm 0.03 \mu \mathrm{g} / \mathrm{mL}$ and standard at $\mathrm{IC}_{50}$ value $28.07 \pm 0.02 \mu \mathrm{g} / \mathrm{mL}$ (Fig. 1).

Leaves extract of $B$. racemosa Lam. has been studying for various pharmacological activities and reported significantly [18]. It contains some isolated coumarins (scopoletin and scopolin) and flavonols (kaempferol and quercetin) compounds [19]. They played major role against various disease treatments. It has been proved by different animal models studies which give many links to develop the future trials [20].

Phytochemical analysis of the extract revealed the presence of various bioactive components such as alkaloids, carbohydrate, protein, amino acids, glycoside, tannins, saponin, flavonoids, steroids, and phenolic compounds [21-24]

B. racemosa Lam. extract possesses significant antidiabetic activity by reducing blood glucose level of STZ-induced diabetic rats [25]. It also exhibits effective normalization in adipose tissues and lipid level. Therefore, the extract showed significant antiadipogenic and hypolipidemic effect. Pharmacologically, it may be useful for the development of new potent herbal medicine for diabetes. These potential effects of extract are used for the treatment of diabetes and related complications [26].

The effective bioactive compounds which are responsible for inhibition were studied by GC-MS analysis technique (Fig. 2). These were reported as phenol,2,4-bis(1,1-dimethylethyl)-, mome inositol, neophytadiene, 6-octen-1-ol,3,7-dimethyl-,propanoate, 16-heptadecenal, and citronellyl butyrate (Table 3 ). Neophytadiene is previously reported as an enzyme inhibitor [27]. Extract has a potential role in the management of insulin resistance and metabolic disorders that accompany diabetes or obesity.

Thus, due to the existence of potent bioactive compounds in extract [28], it showed $\alpha$-amylase inhibitory activity.

\section{CONCLUSION}

The $\alpha$-amylase inhibitory activity showed by $B$. racemosa Lam. leaves ethanol extract has a significant role in management of diabetes. These overall activities due to bioactive phytochemicals were present in the extract. The leaves of B. racemosa Lam. could be a source of natural antidiabetic agent, which has contribution of most significant

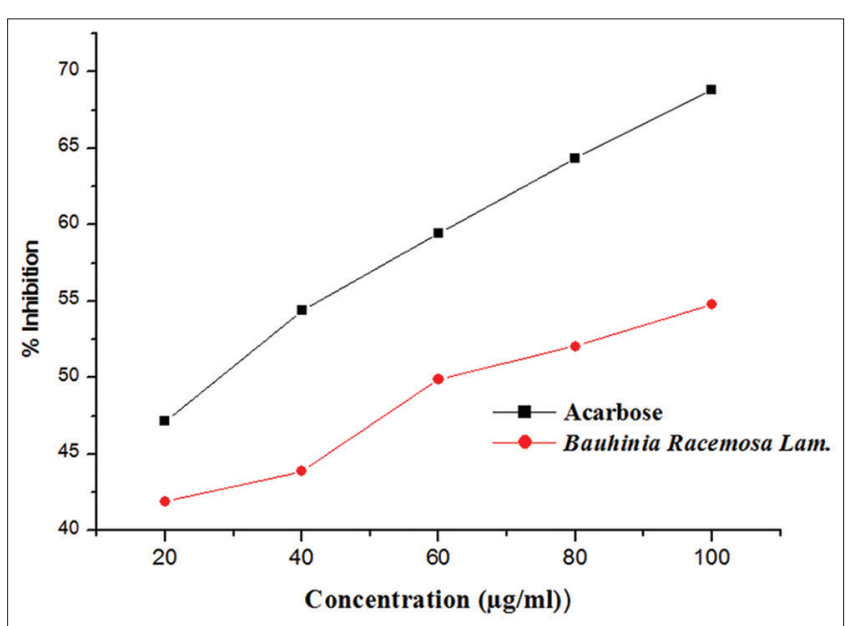

Fig. 1: $\alpha$-amylase inhibition assay of Bauhinia racemosa Lam. leaves ethanol extract 
Table 3: Phytochemicals detected in GC-MS analysis of B. racemosa Lam. extract

\begin{tabular}{lllllll}
\hline Peak \# & R. time & Area & Area\% & Height & Height $\%$ & Name \\
\hline 1 & 16.536 & 67449 & 9.02 & 40237 & 11.74 & Phenol, 2,4-bis (1,1-dimethylethyl)- \\
2 & 19.026 & 209769 & 28.04 & 40409 & 11.79 & Mome inositol \\
3 & 21.276 & 293491 & 39.23 & 157931 & 46.08 & Neophytadiene \\
4 & 21.592 & 43257 & 5.78 & 26964 & 7.87 & 6-Octen-1-ol, 3,7-dimethyl-, propanoate \\
5 & 21.834 & 80268 & 10.73 & 47747 & 13.93 & 16-Heptadecenal \\
6 & 24.633 & 53838 & 7.20 & 29467 & 8.60 & Citronellyl butyrate \\
& & 748072 & 100.00 & 342755 & 100.00 & \\
\hline
\end{tabular}

GC-MS: Gas chromatography-mass spectrometry, B. racemosa: Bauhinia racemosa

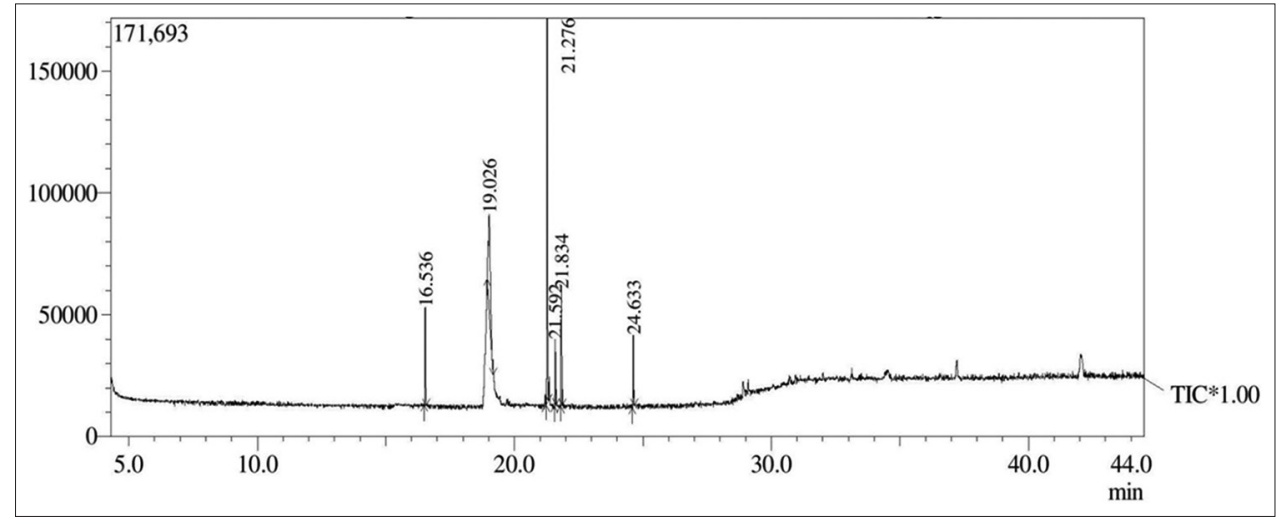

Fig. 2: Gas chromatography-mass spectrometry chromatogram of Bauhinia racemosa Lam. leaves crude extract

therapeutic agents responsible for prevent and management of Type-II diabetes. Thus, it was concluded that B. racemosa Lam. leaves ethanol extract showed in vitro antidiabetic activity. The more investigative study is proposed to validate these claims by separation, isolation, and identifying bioactive components with potential therapeutic value.

\section{ACKNOWLEDGMENT}

The authors are grateful to the Research Institute, Maulana Azad College, Dr. Rafiq Zakaria College for Women, Aurangabad, Director, KFRI, Kerala, HOD and Principal, A. D. College, Kada, for providing facilities.

\section{AUTHOR'S CONTRIBUTION}

Performed collection of sample, extraction, analysis, interpreted data, and wrote the manuscript. Supervised the progress of work, helped in the evaluation of the manuscript, and acted as corresponding author.

\section{CONFLICTS OF INTEREST}

Authors declare no conflicts of interest.

\section{REFERENCES}

1. Wild S, Roglic G, Green A, Sicree R, King H. Global prevalence of diabetes: Estimates for the year 2000 and projections for 2030. Diabetes Care 2004;27:1047-53.

2. Lamer J. The Pharmacological Basis of Therapeutics. $7^{\text {th }}$ ed. New York: MacMillan; 1985.

3. WHO. World Health Organization Expert Committee on Diabetes Mellitus. Second Report, Technical Report Series. Geneva: WHO; 1980.

4. Shettar AK, Vedamurthy AB. Studies on in vitro antidiabetic activities of Hopea ponga and Vitex leucoxylon. Int J Pharm Pharm Sci 2017;9:263-7.

5. Gupta M, Mazumder UK, Kumar RS, Gomathi P, Rajeshwar Y, Kakoti BB, et al. Anti-inflammatory, analgesic and antipyretic effects of methanol extract from Bauhinia racemosa stem bark in animal models. J Ethnopharmacol 2005;98:267-73.

6. El-Khatiba AS, Khaleel AE. Evaluation of some pharmaco-logical properties of different extract of Bauhinia racemosa leaf and Bassia muricata whole plant. Bull Fac Pharm Cairo Univ 1995;33:59-65.

7. Panda P, Das D, Dash P, Ghosh G. Therapeutic potential of Bauhinia racemosa-A mini review. Int J Pharm Sci Rev Res 2015;32:169-79.

8. Panda P, Pal A, Maharana L, Ghosh G. Antibacterial and antioxidant activities of methanolic extract of Bauhinia racemosa. Int J Pharm Pharm Sci 2016;8:277-81.

9. Kumar RS, Sivakumar T, Sunderam RS, Gupta M, Mazumdar UK, Gomathi $\mathrm{P}$, et al. Antioxidant and antimicrobial activities of Bauhinia racemosa L. Stem bark. Braz J Med Biol Res 2005;38:1015-24.

10. Tyagi R, Shukla AA, Shukla RK. Phytochemical screening and pharmacological evaluation of different extracts of plant Casearia tomentosa leaves. Int J Pharm Pharm Sci 2017;9:166-71.

11. Sahu T, Sahu J. Buahinia racemosa (Kachnar): A Review of its medicinal properties. World J Pharm Res 2015;4:686-96.

12. Ezuruike UF, Prieto JM. The use of plants in the traditional management of diabetes in Nigeria: Pharmacological and toxicological considerations. J Ethnopharmacol 2014;155:857-924.

13. Behera1 B, Yadav D. Current researches on plants having antidiabetic potential: An overview, research and reviews. J Bot Sci 2013;2:4-17.

14. Bhutkar MA, Bhise SB. In vitro assay of alpha amylase inhibitory activity of some indigenous plants. Int J Chem Sci 2012;10:457-62.

15. Gawade BN, Farooqui M. In vitro alpha amylase inhibitory activity study of Zizyphus mauritiana leaves ethanol extract. J Med Chem Drug Disc 2017;3:67-76.

16. Ghumare P, Jirekar DB, Farooqui M, Naikwade SD. Phytochemical analysis of petroleum ether extract of some selected medicinal plants leaves. Indian J Adv Plant Res 2014;1:20-3.

17. Tiwari P, Kumar B, Kaur M. Phytochemical screening and extraction: A review. Int Pharm Sci 2011;1:98-106.

18. Ghumare P, Jirekar DB, Farooqui M, Naikwade SD. Biological activity of aqueous extract of some medicinal plants. Der Chem Sin 2014;5:65-70

19. Soni V, Jha AK, Dwivedi J, Soni P. Traditional uses, phytochemistry and pharmacology of Bauhinia racemosa Lam-a review. TANG 2015;5:1-7. Available from: http://www.e-tang.org.

20. Kulkarni SS, Lanjewar RB, Gadegone SM. A review on levodopa and beta-sitosterol and its pharmacological actions in Bauhinia racemosa, Canavalia gladiata, Vigna vexillata medicinal Plants. J Med Plants Stud 2016;4:259-64.

21. Pawar DS, Nasreen S. Phytochemical screening and antifungal activity of Bauhinia racemosa and Dolichandrone falcate. Int J Appl Res 2016;2:243-5 
22. Krishnamoorthi R. Phytochemical screening and antioxidant activity of Justicia tranquebariensis and Bauhinia racemosa. Int J Pharm 2015;2:362-7.

23. Ghumare P, Jirekar DB, Farooqui M, Naikwade SD. Preliminary phytochemical screening and antibacterial activity of Bauhinia racemosa Leaves. Biosci Biotech Res Asia 2014;11:1-4

24. Akelesh T, Gopal V, Jeyabalan G, Johnson S, Chander JU, Manavalan R, et al. Preliminary phytochemical screening of the extracts of Bauhinia racemosa Linn. World J Pharm Pharm Sci 2017;6:1565-72.

25. Killari KN, Konduri P, Shaik A, Reddy Vennapusa JK, Talluri M. Protective effect of Bauhinia racemosa against streptozotocin induced diabetes male infertility complications. Int Res J Pharm 2017;8:74-9.

26. Kumar V, Rathore K, Jain P, Ahmed Z. Biological activity of Bauhinia racemosa against diabetes and interlinked disorders like obesity and hyperlipidemia. Clin Phytosci 2017;3:1-9.

27. Kanimozhi D, Bai VR. Analysis of bioactive components of ethanolic extract of Coriandrum sativum L. Int J Res Pharm Sci 2012;2:97-110.

28. Kalpana S, Ramakrushna B, Anitha S. Evaluation of in vitro antioxidant and $\alpha$-amylase inhibitory activity of Phyllanthus indofischeri Bennet. Int J Pharm Pharm Sci 2016;8:131-6. 